\title{
MINIONE KRAJOBRAZY ZATOKI PUCKIEJ
}

\section{Walory przyrodnicze i gospodarcze Zatoki Puckiej}

Zatoka Pucka jest subregionem Zatoki Gdańskiej, wydzielonym umowną granicą na linii Cypel Helski-Przylądek Orłowski w Gdyni (rys. 1). W tak przyjętych granicach wyróżnia się Zatokę Pucką wewnętrzną i Zatokę Pucką zewnętrzną. Rozdziela je naturalna granica - piaszczysta łacha, częściowo zanurzona, zwana Ryfem Mew (albo Rybitwią Mielizną). Akweny te mają różne reżimy hydrologiczne i istotne różnice ekosystemowe. Wewnętrzna część Zatoki Puckiej (zwana także Zalewem Puckim lub Małym Morzem) ma charakter płytkiej i prześwietlonej laguny, natomiast zewnętrzna część należy do mas wodnych Zatoki Gdańskiej (Majewski, Lauer, 1994).

W Zatoce Puckiej wewnętrznej, akwenie płytkim i osłoniętym, są szczególnie korzystne warunki do rozwoju życia na dnie (Wojtusiak, 1950). Z uwagi na duży udział wód słodkich oraz na niewielkie zasolenie występują tam obok siebie gatunki roślin i zwierząt słodkowodnych, a także słonowodnych. W efekcie jest to akwen o największym zróżnicowaniu biologicznym na Bałtyku Właściwym (Żmudziński, 1994).

Dno Zatoki Puckiej wewnętrznej oraz płytkie wody przybrzeżne Zatoki Puckiej zewnętrznej aż do lat 70. XX w. porastały bujne łąki podwodne (Klekot, 1980; Kruk-Dowgiałło, 1998), których głównym składnikiem była trawa morska Zostera marina oraz glony makroskopowe - krasnorost widlik Furcellaria lumbricalis i brunatnica morszczyn Fucus vesiculosus (Wojtusiak, 1950). Zwarte skupiska tworzyły także inne rośliny: ramienica chara, zamętnica błotna i rdestnice. W tamtym czasie na plaże Zatoki Puckiej wewnętrznej morze wyrzucało znaczne ilości trawy morskiej oraz wodorostów: widlika i morszczynu. Oszacowano, że na odcinku brzegu pomiędzy Gdańskiem a Gdynią biomasa widlika wyrzuconego na brzeg wynosiła 15-18 tys. ton, natomiast biomasa morszczynu 


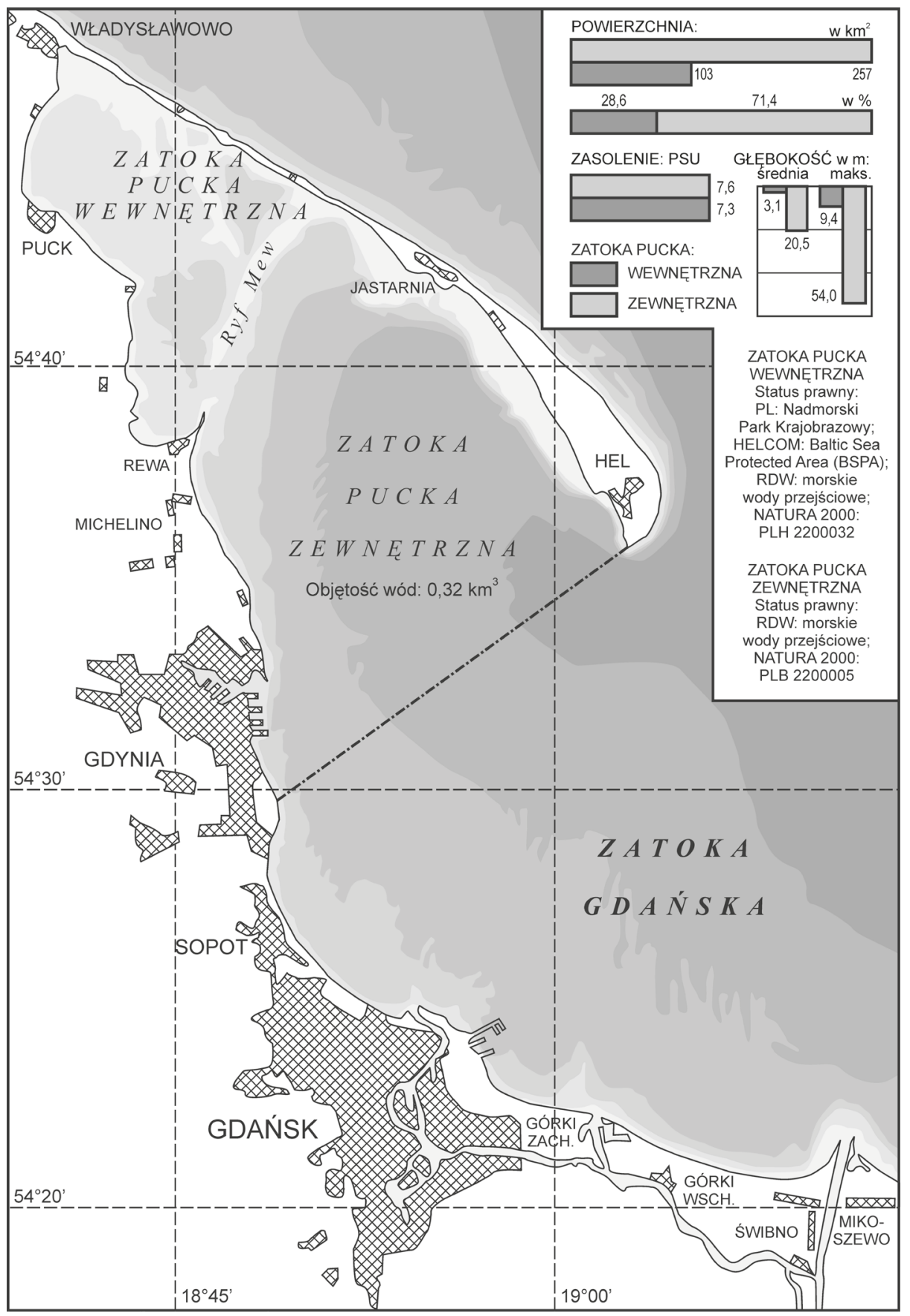

Rysunek 1. Usytuowanie Zatoki Puckiej Źródło: Nowacki (1993) 
6-7 tys. ton (Czapke, 1961). Z kolei w badaniach podwodnych zasoby widlika na dnie Zatoki oceniono na 11,5 tys. ton (Ciszewski, Demel, Ringer, Szatybełko, 1962).

Na podstawie tych szacunków podjęto decyzję o wykorzystaniu wodorostów do produkcji agar-agaru oraz kwasu alginowego (agar-agar i kwas alginowy to substancje żelujące, mające zastosowanie w przemyśle spożywczym, farmaceutycznym i kosmetycznym). W tym celu w $1961 \mathrm{r}$. utworzono Zakład Doświadczalny Przetwórstwa Wodorostów Morskich w Pucku, jednak z powodu wyczerpania się surowca w 1972 r. zakończono produkcję agar-agaru (Trokowicz, Andrulewicz, 2019).

Jeszcze w latach 70. XX w. Zatoka Pucka była miejscem obfitego połowu ryb w ilościach od kilkudziesięciu do kilkuset ton na rok, w tym: węgorza łowiono około 25 ton, belony - do 40 ton, okonia - do 40 ton, płoci - do 160 ton, szczupaka - do 40 ton, śledzia - do 100 ton, troci - około 12 ton (rys. 2) (Skóra, 1993). Łowiono także około 4 ton siei, która w kolejnych latach całkowicie wyginęła w Zatoce Puckiej. Zatoka była miejscem pracy i źródłem żywności pochodzenia morskiego dla wielu setek rybaków (fot. 1-4). Pozyskiwano także znaczne dochody ze sprzedaży

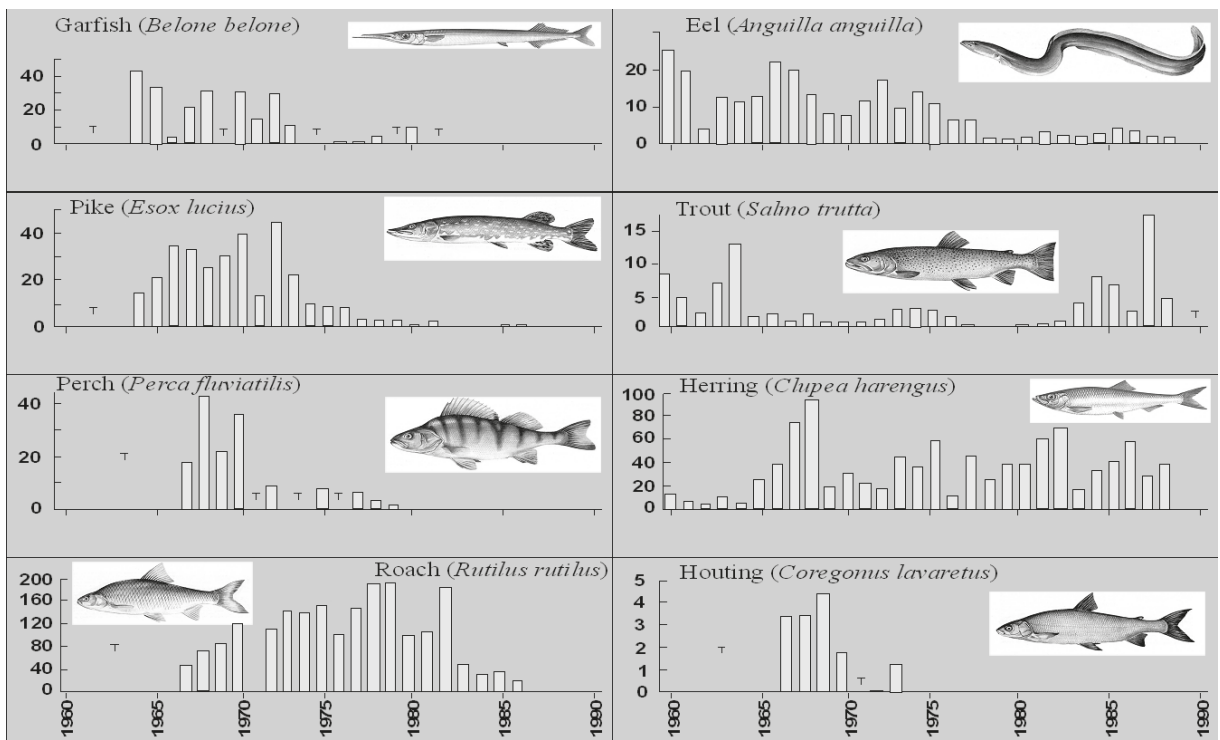

Rysunek 2. Połowy ośmiu najważniejszych gatunków ryb Zatoki Puckiej wewnętrznej, w tonach (na podstawie statystyk Zrzeszenia Rybaków Morskich)

Objaśnienia: garfish - belona, eel - węgorz, pike - szczupak, trout - troć, perch - okoń, herring - śledź, roach - płoć, houting - sieja

Źródło: Skóra (1993, s. 455-467) 


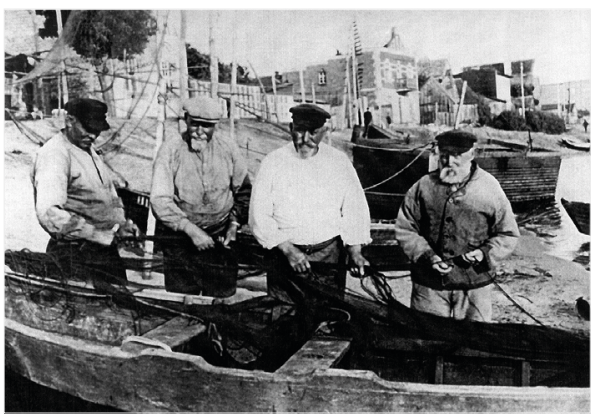

Fotografia 1. Krajobrazy „rybackiego Helu" - lata 30. XX w. Rybacy przed wypłynięciem w morze Źródło: fotografia ze zbiorów T. Muży

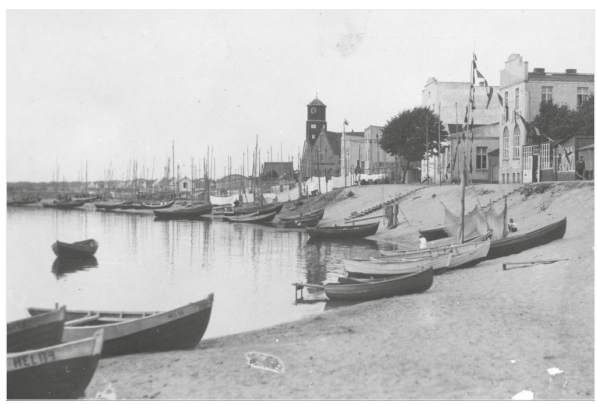

Fotografia 3. Minione krajobrazy „rybackiego Helu” - brzeg morski na odcinku portu rybackiego w Helu w latach 30. XX w.

Źródło: fotografia ze zbiorów T. Muży

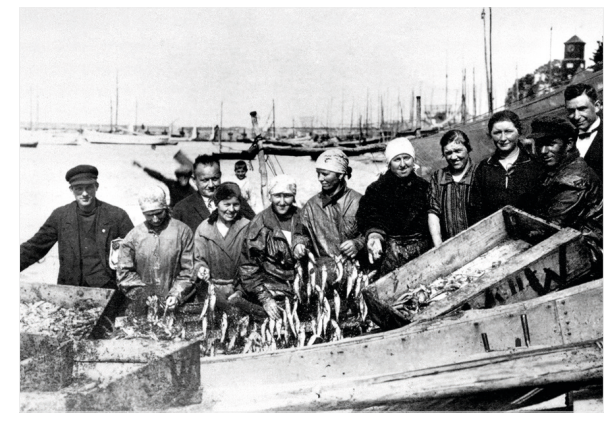

Fotografia 2. Krajobrazy "rybackiego Helu” - lata 30. XX w. Rybacy i ich rodziny po powrocie z połowu ryb Źródło: fotografia ze zbiorów T. Muży

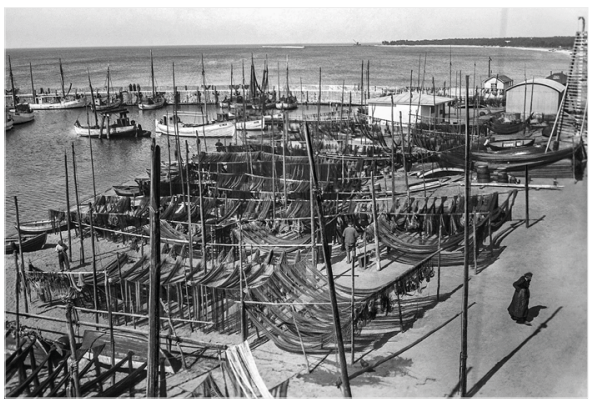

Fotografia 4. Minione krajobrazy „rybackiego Helu” - suszenie sieci w porcie rybackim w Helu w latach 30. XX w.

Źródło: fotografia ze zbiorów T. Muży

ryb, głównie na targowiskach Trójmiasta i ulicach Gdyni. Przykładowo, rybak na Zatoce wystawiał jednorazowo do 5 tys. haków, na które łowił do $200 \mathrm{~kg}$ węgorza $^{1}$.

W latach 50. i 60. XX w. młodzi mieszkańcy Helu, w niektórych okresach (prawdopodobnie tarła), łowili płocie, szczupaki oraz okonie kaszorami i wędkami, wprost z nabrzeża portowego w Helu. Jak wspominają, ich wiaderka szybko zapełniały się złowionymi rybami².

${ }^{1}$ Informacje pozyskane od Romana Boszke - rybaka, mieszkańca Helu.

${ }^{2}$ Informacje pozyskane od Romana Boszke i Tadeusza Muży - rybaków z Helu. 
Jeszcze na początku lat 70. XX w. w Zatoce Puckiej, niemalże w czasie każdego nurkowania na zatrzymanym oddechu, płetwonurek mógł zobaczyć liczne węgorze, okazy dużych szczupaków, ławice okoni i płoci³.

\section{Degradacja Zatoki Puckiej i jej przyczyny}

Pod koniec lat 70. XX w. stan środowiska Zatoki Puckiej zaczął się gwałtownie pogarszać - znikały łąki podwodne trawy morskiej, wyginęły makroglony (morszczyn i widlik), malały zasoby ryb przemysłowych. Nastąpił gwałtowny rozwój jednorocznych nitkowatych brunatnic $P y$ laiella littoralis (fot. 5, 6) oraz ciernika, uważanego za „rybi chwast” (Skóra, 1993).

Wraz z pogorszeniem zasobów ichtiofauny zaczęła zmniejszać się liczba rybaków łowiących na Zatoce, a co za tym idzie ubywało też łodzi rybackich. Miejscowości rybackie zaczęły tracić walory kulturowo-krajobrazowe, takie jak: kutry rybackie w portach i przystaniach oraz łodzie na piaszczystych brzegach Zatoki, sieci suszące się na plażach i na podwórkach chat rybackich (fot. 3 i 4), ręczne kołowroty do wciągania łodzi na brzeg, tyczki z choragiewkami do oznakowania wystawionych sieci i inne.

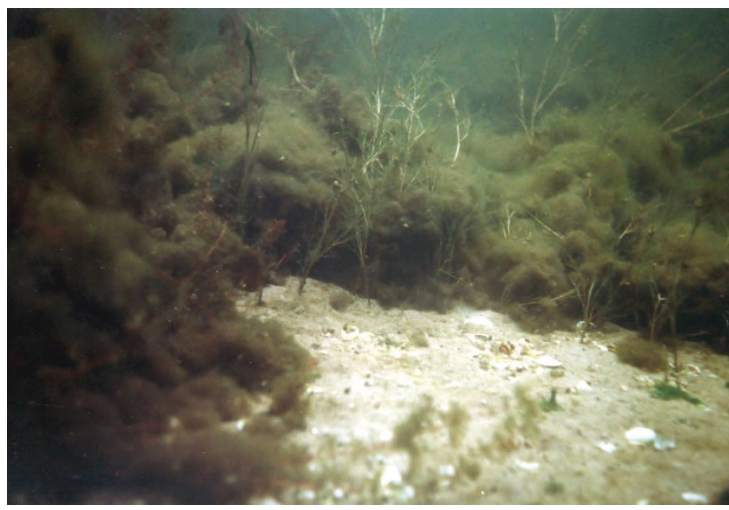

Fotografia 5. Masowy rozwój nitkowatych brunatnic (Pylaiella littoralis) na dnie Zatoki Puckiej, który zakłóca rozwój roślin makroskopowych, a gnicie brunatnic powoduje pogorszenie się warunków tlenowych w osadach dennych Źródło: P. Ciszewski (lata 80. XX w.)

${ }^{3}$ Informacje pozyskane od: inż. Zygfryda Naczka, Andrzeja Redlarskiego, dr. Paulina Ciszewskiego, Mariana Smorawskiego oraz obserwacje własne autora. 


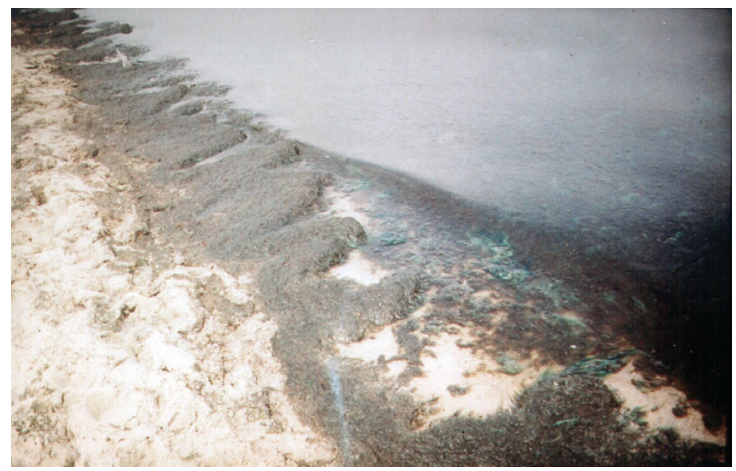

Fotografia 6. Brunatnice (Pylaiella littoralis) na brzegu Zatoki Puckiej - ich obecność i gnicie powodują degradację walorów estetycznych i rekreacyjnych plaży Źródło: P. Ciszewski (lata 80. XX w.)

Pod koniec lat 50. XX w. w Zatoce Puckiej notowano jeszcze występowanie morszczynu i widlika, ale w latach 80 . glonów tych już tam nie było (Kruk-Dowgiałło, 1994). Te wieloletnie glony (wodorosty), które tworzyły doskonałe miejsce tarła, wychowu i schronienia wielu gatunków ryb, zostały zastąpione przez szybkorosnące, jednoroczne nitkowate brunatnice. W latach 90. odnotowano też brak trawy morskiej (Kruk-Dowgiałło, 1994; Pliński, 1993). Stwierdzono także, że w osadach dennych, w wielu miejscach, szczególnie pod warstwą glonów zalegających na dnie, panował deficyt tlenu, a nawet wytwarzał się siarkowodór (Ciszewski, Kruk-Dowgiałło, Andrulewicz, 1991).

W konsekwencji wielu rybaków, często pochodzących z rodzin trudniących się rybołówstwem od wielu pokoleń, przekwalifikowało się na hotelarzy, którzy zaczęli żyć z turystyki. Natomiast turyści, spragnieni "świeżo złowionej rybki”, otrzymują rybę z zamrażarki bądź rybę hodowlaną lub spoza Bałtyku.

Na obszarze Zatoki Puckiej, świadomie lub nieświadomie, popełniono wiele błędów wynikających z chęci bogacenia się i rozwoju gospodarczego kosztem środowiska przyrodniczego. Na przełomie lat 60. i 70. XX w. osuszono podmokłe brzegi Zatoki, głównie w ujściu rzeki Płutnicy. $Z$ tego powodu zniknęły miejsca rozrodu (tarliska) szczupaka, który w Zatoce Puckiej miał doskonałe warunki bytowania i dorastał do imponujących, kilkukilogramowych rozmiarów. W latach 60 ., w celu pozyskania krasnorostu widlika (Furcellaria fastigiata, obecnie F. lumbricalis) do produkcji rodzimego agar-agaru, rozpoczęto na dużą skalę wydobycie $\mathrm{z}$ dna Zatoki widlika i towarzyszącego mu morszczynu. Dragowanie to musiało 
przyczynić się do zaniku wspomnianych glonów i mogło mieć także destrukcyjny wpływ na łąki podwodne trawy morskiej (Trokowicz, Andrulewicz, 2019).

Jednakże najbardziej brzemienna w negatywne skutki środowiskowe była decyzja o odprowadzaniu ścieków komunalnych z Gdyni i miejscowości położonych nad Zatoką bezpośrednio do brzegów Mechelinek i Swarzewa. Ścieki te, początkowo oczyszczane tylko mechanicznie, spowodowały skażenia sanitarne wód, zamknięcie plaż na wiele lat i zachwianie równowagi biologicznej ekosystemu Zatoki. Zamiast roślin makroskopowych rolę głównego konsumenta soli odżywczych w Zatoce przejęły jednoroczne nitkowate brunatnice (fot. 5), które zalegając na dnie morskim, powodowały okresowe braki tlenu w osadach dennych. Zdaniem autora, nastąpiło przebudowanie się reżimu ekologicznego Zatoki (ang. regime shift), która straciła swój charakter oligotroficzny (ubogożywny) i stała się ekosystemem eutroficznym (bogatożywnym).

Do błędnych decyzji gospodarczych należy zaliczyć także refulację (tj. przepompowanie piasku z pogłębiarki na brzeg morski) plaży po odmorskiej stronie Półwyspu Helskiego (1989-1996) z użyciem piasku z Zatoki Puckiej. Działanie to, chociaż nie spowodowało szkód w skali całej Zatoki, jest przykładem kosztownego i niezrozumiałego błędu. Osad pobrany z dna Zatoki Puckiej, z powodu dużej zawartości torfu i glinki jeziornej, był nieprzydatny do ochrony brzegu morskiego. Natomiast na dnie Zatoki pozostały głębokie wyrobiska, które wypełniły się gnijącą materią organiczna, a w konsekwencji także siarkowodorem.

Do listy osobliwych pomysłów dotyczących wykorzystania lub „poprawienia" walorów Zatoki Puckiej należy zaliczyć także propozycje niektórych naukowców, jak np. projekt utwardzenia części dna Zatoki Puckiej wewnętrznej i wybudowania sieci pensjonatów i hoteli (tzw. projekt „Floryda”). Zamysł ten wiązał się z propozycją zagospodarowania odpadów fosfogipsu pochodzącego z Gdańskich Zakładów Nawozów Fosforowych. Zgłaszano także projekt przekopania Półwyspu Helskiego, co miało poprawić wymianę wód w Zatoce i zmniejszyć poziom zanieczyszczeń. Proponowano również wybudowanie autostrady na Ryfie Mew oraz wzniesienie opaski betonowej wokół Kępy Redłowskiej (łącznie z cyplem orłowskim). Na szczęście pomysłów tych nie zrealizowano ${ }^{4}$.

Omawiając przyczyny degradacji Zatoki Puckiej, nie można też pominąć nadmiernej eksploatacji zasobów ryb przemysłowych. Wraz z ulepszaniem narzędzi połowowych (np. wprowadzenie sieci plastikowych

${ }^{4}$ Informacje własne. 
w miejsce tradycyjnych sieci lnianych/konopnych), rozwojem techniki połowowej (np. użycie łodzi motorowych i większych kutrów), a także z powodu rosnącego zapotrzebowania konsumentów na rybę (zwiększenie presji na ichtiofaunę) Zatoka Pucka została "przełowiona”.

Ostateczną oznaką „,zagłady” zasobów ryb przemysłowych w Zatoce była masowa śmiertelność (pomór) węgorzy i płastug wiosną 1980 i 1981 r. (fot. 7). Zdaniem autora, przyczyną masowej śmiertelności tych ryb było wytworzenie się warunków siarkowodorowych w osadach dennych Zatoki. Siarkowodór jako kwas spowodował uszkodzenie błon śluzowych zimujących na dnie węgorzy. Umożliwiło to atak bakterii chorobotwórczych na te ryby - w badaniach bakteriologicznych stwierdzono posocznicę bakteryjną. Dotyczyło to także płastug, bytujących na dnie Zatoki.

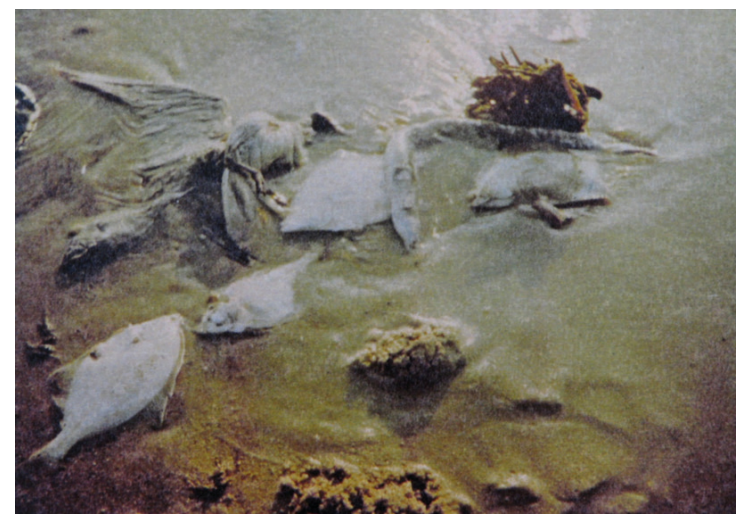

Fotografia 7. Fragment plaży nad Zatoką Pucką w okresie masowej śmiertelności węgorzy i płastug w $1980 \mathrm{r}$. Źródło: R. Wiliński (1980)

\section{Stan obecny i przyszłość Zatoki Puckiej}

W ostatnich latach zauważa się znaczny postęp w zakresie ochrony środowiska Zatoki Puckiej. Rozpoczęto porządkowanie gospodarki ściekowej i gospodarki odpadami w obrębie zlewiska Zatoki. Zmodernizowano oczyszczalnię ścieków „Dębogórze" i oczyszczalnię ścieków „Swarzewo”. Po wybudowaniu rurociągu odprowadzającego ścieki z oczyszczalni „Dębogórze" do bardziej dynamicznej Zatoki Puckiej zewnętrznej oraz po odprowadzeniu ścieków z oczyszczalni "Swarzewo" poza Zatokę Pucką nastąpiła poprawa stanu sanitarnego kąpielisk nad Zatoką, a więc 
otwarto plaże. Poprawiły się parametry hydrochemiczne wód Zatoki. Obecnie obserwuje się pierwsze objawy (jeszcze niepotwierdzone badaniami) odnowy ekosystemu, takie jak prawdopodobne zwiększanie się powierzchni dna porośniętego trawą morską.

W obrębie Polskich Obszarów Morskich Zatoka Pucka ma nadal najwyższą różnorodność biologiczną. $Z$ tego względu została wpisana na listę obszarów Unii Europejskiej NATURA 2000. Zatoka Pucka wewnętrzna jako obszar „siedliskowy” (NATURA 2000: PLH 2200032) i Zatoka Pucka zewnętrzna jako obszar „ptasi” (NATURA 2000: PLB 2200005).

Pomimo podejmowania wyżej wymienionych przedsięwzięć na rzecz ochrony Zatoki jest ona nadal akwenem nadmiernie zeutrofizowanym (przeżyźnionym). W okresie wczesnej wiosny (marzec/kwiecień) następuje gwałtowny rozwój nitkowatych brunatnic, które pokrywając rośliny makroskopowe, ograniczają do nich dostęp światła (fot. 8), a następnie gnijąc, pogarszają warunki tlenowe w osadach dennych. Nitkowate brunatnice są także doskonałym siedliskiem dla ciernika (fot. 9).

W sezonie letnim Zatoka jest nadmiernie obciążona aktywnością turystyczną. Przybyło wiele źródeł hałasu, w tym głównie bardzo głośne skutery wodne. Ich wpływ na środowisko jest słabo poznany i nie można wykluczyć, że wysoki poziom hałasu ma negatywny wpływ na niektóre zwierzęta morskie (ssaki, ryby). Jednocześnie obserwuje się działania niezgodne z prawem, takie jak zmiany linii brzegowej oraz niszczenie roślinności dennej i szuwarów Zatoki, które służą poszerzeniu przestrzeni turystycznej. W efekcie takich działań dochodzi do niszczenia tarlisk oraz miejsc wychowu i schronienia ryb.

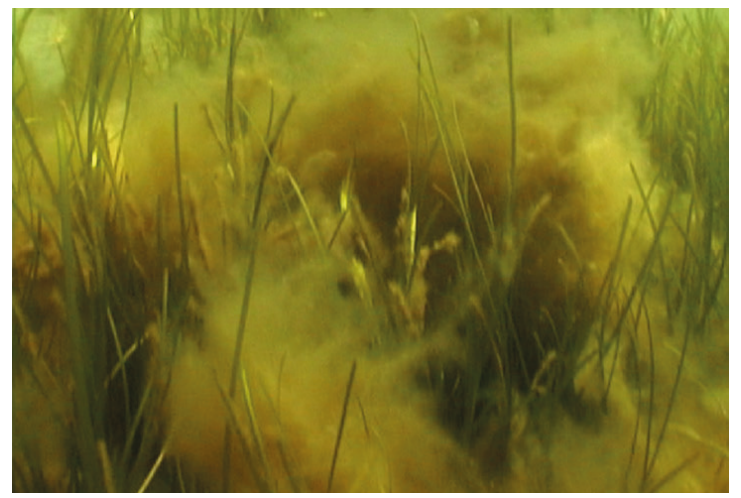

Fotografia 8. Nitkowate brunatnice na dnie Zatoki - współczesny krajobraz dna zbiornika zeutrofizowanego w okresie wczesnowiosennym Źródło: S. Andrulewicz (2018) 


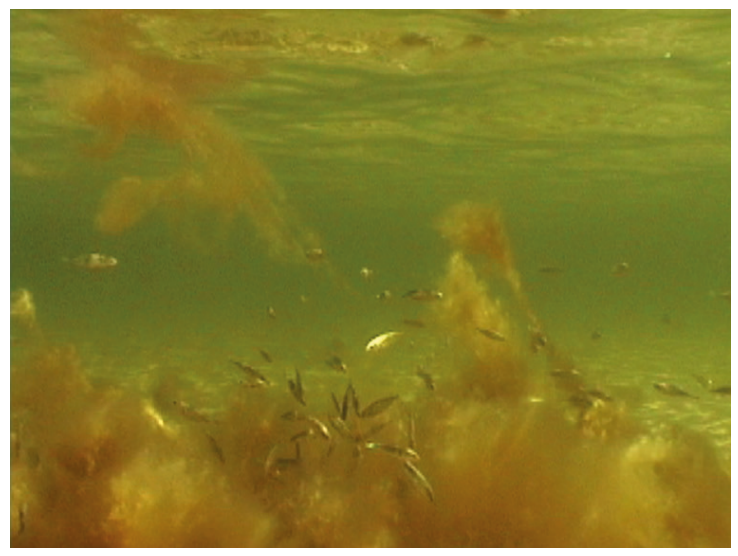

Fotografia 9. Nitkowate brunatnice na dnie Zatoki jako siedlisko dla ciernika - współczesny krajobraz dna zbiornika zeutrofizowanego w okresie wczesnowiosennym Źródło: S. Andrulewicz (2018)

Rośnie też presja na brzegi Zatoki Puckiej, głównie ze strony licznych deweloperów, a ich aktywność w zabudowywaniu najbardziej atrakcyjnych odcinków wybrzeża nie zawsze jest powstrzymywana przez lokalne władze. Jednocześnie obserwuje się degradację naturalnego krajobrazu brzegu morskiego wskutek budowy betonowych lub kamiennych umocnień, chroniących przed nie zawsze oczywistą erozją. W miejscu przystani rybackich i piaszczystych plaż Zatoki, na które wyciągane były łodzie, powstają ",twarde", betonowe budowle - rzekomo nowoczesne

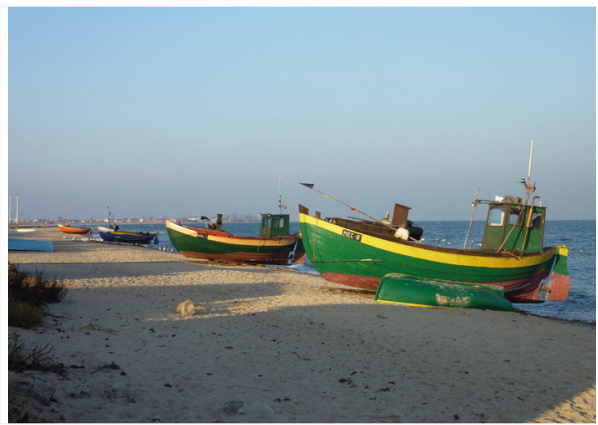

Fotografia 10. Zmiany krajobrazu morskiego w Gdyni-Oksywiu - fragment plażowej przystani rybackiej przed budową nowoczesnej przystani rybackiej Źródło: E. Andrulewicz (2012)

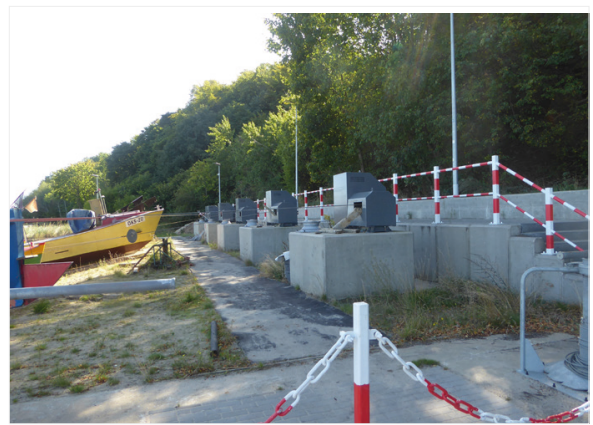

Fotografia 11. Zmiany krajobrazu morskiego w Gdyni-Oksywiu - fragment tego samego brzegu po wybudowaniu nowoczesnej przystani rybackiej Źródło: E. Andrulewicz (2020) 


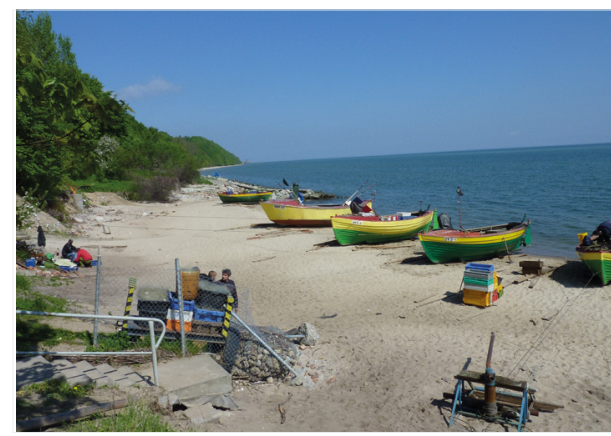

Fotografia 12. Zmiany krajobrazowe w Mechelinkach - łodzie rybackie na piaszczystym brzegu Zatoki Puckiej w 2012 r. Źródło: E. Andrulewicz (2012)

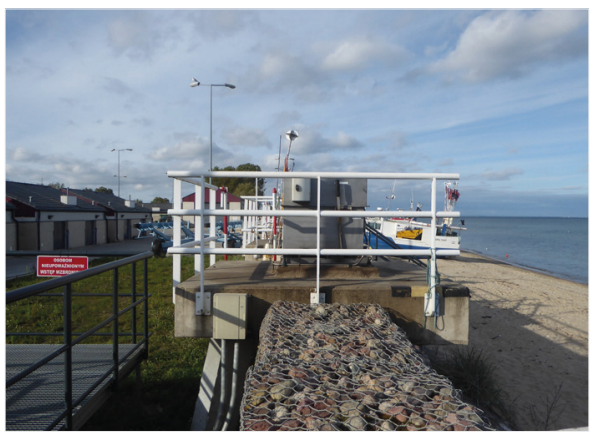

Fotografia 13. Zmiany krajobrazowe w Mechelinkach - fragment „nowoczesnego" portu rybackiego w Mechelinkach w $2020 \mathrm{r}$. Źródło: E. Andrulewicz (2020)

porty, których przeznaczenie jest niezupełnie jasne. Buduje się falochrony, wyciągarki elektryczne do łodzi, mola i magazyny na ryby, pomimo tego, że w Zatoce Puckiej nie ma już zasobów ryb odpowiadających skali budowanych obiektów. Ginie dawny, naturalny charakter i klimat wybrzeża morskiego Zatoki Puckiej (fot. 10-13).

\section{Podsumowanie}

Można przyjąć, że nawet przy dalszym ograniczaniu dopływu związków azotu i fosforu oraz po ewentualnej re-introdukcji pierwotnych makroglonów i ichtiofauny, Zatoka Pucka nie wróci już do stanu sprzed jej degradacji. Wytworzy się jakiś inny ekosystem i inny krajobraz podwodny. Pokazują to dotychczasowe doświadczenia z rekultywacji zdegradowanych zbiorników wodnych (głównie jezior) w wielu miejscach na świecie.

Zatoka Pucka, którą poznawał K. Demel i pamiętają jeszcze starsi rybacy, a także pierwsi płetwonurkowie, w tym autor tego artykułu, to świat miniony.

\section{Podziękowania}

Serdeczne podziękowania składam Panu Tadeuszowi Muży, kierownikowi Muzeum Rybołówstwa w Helu, za przesłanie przedwojennych zdjęć rybaków helskich i „rybackiego” Helu oraz dr Lidii Kruk-Dowgiałło, 
dr hab. Elżbiecie Łysiak-Pastuszak, prof. Zbigniewowi Otrembie, dr hab. Elżbiecie Zawadzkiej-Kahlau oraz Państwu Romanowi i Urszuli Boszke za przeczytanie manuskryptu i cenne uwagi merytoryczne.

\section{Bibliografia}

Andrulewicz, E., Janta, A. (1997). Zatoka Pucka Wewnętrzna. W: A. Janta (red.), Nadmorski Park Krajobrazowy (123-137). Władysławowo: Wydawnictwo Nadmorskiego Parku Krajobrazowego.

Ciszewski, P., Demel, K., Ringer, Z., Szatybełko, M. (1962). Zasoby widlika w Zatoce Puckiej oszacowane metodą nurkowania. Prace Morskiego Instytutu Rybackiego w Gdyni, 11 (A), 9-36.

Ciszewski, P., Kruk-Dowgiałło, L., Andrulewicz, E. (1991). A study on pollution of the Puck Lagoon and possibility of restoring the lagoon's ecological state. Acta Ichthyologica et Piscatoria, XXI, 29-37. https://doi.org/10.3750/AIP1991.21.S.03

Czapke, K. (1961). Agar-agar z krajowego surowca. Przemyst Spożywczy, 15 (11), 12-17.

Klekot, L. (1980). Zatoka Pucka osobliwością hydrologiczną Bałtyku. Oceanologia, 12, 109-123.

Kruk-Dowgiałło, L. (1994). Przyczyny zmian struktury roślinności dennej Zatoki Puckiej oraz możliwości sterowania jej występowania. W: Problemy ochrony środowiska przyrodniczego Morza Battyckiego i strefy nadmorskiej, (s. 47-63). Warszawa: Instytut Ochrony Środowiska.

Kruk-Dowgiałło, L. (1998). Phytobenthos as indicator of the of the state of environment of the Gulf of Gdansk. Oceanological Studies, XXVII (4), 105-123.

Majewski, A., Lauer, Z. (red.) (1994). Atlas Morza Battyckiego. Warszawa: Instytut Meteorologii i Gospodarki Wodnej.

Nowacki, J. (1993). Morfometria Zatoki. W: K. Korzeniewski (red.), Zatoka Pucka (s. 71-78). Gdańsk: Instytut Oceanografii UG.

Pliński, M. (red.) (1993). Problemy Ekologiczne Ziemi Puckiej-stan i środki zaradcze. GdańskKrokowa: Wyd. Instytut Oceanologii PAN - Sopot.

Skóra, K. (1993). Ichtiofauna. W: K. Korzeniewski (red.), Zatoka Pucka (s. 455-467). Gdańsk: Instytut Oceanografii UG.

Trokowicz, D., Andrulewicz, E. (2019). Wydobycie i przetwórstwo wodorostów z Zatoki Puckiej. Wiadomości Rybackie, 11-12 (232), 20-23.

Wojtusiak, R.J. (1950). W morskiej toni. Z wędrówek przyrodnika w hetmie nurkowym po dnie morza. Warszawa: Państwowe Zakłady Wydawnictw Szkolnych.

Żmudziński, L. (1994). Flora i fauna morska. W: A. Majewski, Z. Lauer (red.), Atlas Morza Bałtyckiego (s. 165-184). Warszawa: Instytut Meteorologii i Gospodarki Wodnej.

\section{MINIONE KRAJOBRAZY ZATOKI PUCKIEJ}

Abstrakt: Na podstawie opracowań i publikacji naukowych oraz wspomnień starszych rybaków i mieszkańców rejonu Zatoki Puckiej opisano stan Zatoki z lat 50. i 60. XX w. Przeanalizowano przyczyny degradacji Zatoki, w tym wskazano na konkretne przedsięwzięcia oraz decyzje gospodarcze, które doprowadzały do niekorzystnych zmian 
przyrodniczych. Omówiono działania podjęte na rzecz ochrony tego akwenu, które polegały głównie na uporządkowaniu gospodarki ściekowej w obrębie zlewiska. Wskazano, że Zatoka Pucka nadal jest nadmiernie obciążona dopływem związków odżywczych, a także eksploatacją turystyczną. Rośnie presja deweloperów i prowadzone są modernizacje portów rybackich, wskutek czego w rejonie Zatoki Puckiej wciąż zachodzą niekorzystne zmiany krajobrazowe.

Słowa kluczowe: degradacja Zatoki Puckiej, presja antropogeniczna, ochrona środowiska morskiego, degradacja krajobrazu.

\title{
PAST LANDSCAPES OF THE BAY OF PUCK
}

\begin{abstract}
The study presents the basic hydrological features of the Bay of Puck which have allowed for the emergence and development of a diverse flora and fauna, including a rich ichthyofauna. On the basis of research and scientific publications, as well as the memories of older fishermen and inhabitants of the region, its state in the 1950s and 1960s is described. The reasons for its degradation were analyzed, including the specific projects and economic decisions that led to unfavorable environmental change. Action taken to protect the bay mainly consists of organizing wastewater management within the catchment area. It is pointed out that the Bay of Puck is still too heavily burdened with an inflow of nutrients as well as tourist overexploitation. Pressure from developers and the modernization of ports and fishing harbors is growing. As a result, unfavorable landscape changes in the Bay of Puck are still taking place.
\end{abstract}

Keywords: degradation of the Bay of Puck, anthropogenic pressure, protection of the marine environment, landscape degradation. 